\title{
On the long-ignored scientific achievements of the Belgica expedition 1897-1899
}

\author{
Patrick De Deckker (iD \\ Research School of Earth Sciences, The Australian National University, Canberra, Australia
}

\begin{abstract}
The Belgica expedition, which left Belgium in August 1897, was the first to spend 13 months continuously in Antarctic waters, before returning in late 1899. This was not only an exploratory venture, as new lands and oceans were charted, but more importantly it was an exceptional and successful scientific voyage. After the return of the expedition, a vast array of scientific data was processed and eventually 92 publications in some nine volumes funded by the Belgica Commission appeared over 40 years as a series called Résultats du voyage de la Belgica en 1897-99 sous le commandement de A. de Gerlache de Gomery - rapports scientifiques. Disappointingly, those significant results have been mostly ignored in the scientific literature and the paper here aims to inform scientists of the achievements of the Belgica expedition and where to obtain the information. Many of the climatological and oceanographic data obtained by the expeditioners ought to be examined in line with the changes that are occurring today in the Antarctic Peninsula region as a result of global warming. Some of the Belgica data form an important database to critically assess environmental changes over 120 years in the region of the Antarctic Peninsula.
\end{abstract}

\section{KEYWORDS}

Antarctic Peninsula; Gerlache Strait; climate change; glaciology; meteorology; oceanography

\section{The SY Belgica}

The Norwegian vessel called Patria was purchased by Adrien de Gerlache, who arranged for it to be refurbished with well-designed scientific laboratories, and insulated with felt to protect against the cold, and its hull reinforced to allow safe sailing into the pack ice. The expedition was sponsored by the Royal Belgian Geographical Society, the Belgian government, as well as many benefactors and many Belgian cities and towns through a great variety of fund raising. This small vessel was renamed SY Belgica (SY stands for Steamed Yacht) and it carried the flag of the Yacht Club of Antwerp. Its dimensions were $34.6 \mathrm{~m} \times 7.54 \mathrm{~m} \times 4.09 \mathrm{~m}$, and when loaded it displaced $590 \mathrm{~m}^{3}$ and was 172 tonnes it was fitted with a 150 horsepower engine.

The expedition was truly international in nature as by the time it commenced its scientific investigations in the Beagle Channel, before venturing into Drake Passage and beyond, the expeditioners consisted of nine Belgians, six Norwegians, two Poles, one Romanian and one American (Table 1). The eldest member was 34 years old and the youngest, barely 17 .

\section{The Belgica expedition}

After more than a year of careful preparation, the SY Belgica left Antwerp on 16 August 1897, just over 120 years ago. The general purpose of the voyage was exploratory and to gather a vast amount of new scientific information. One principal aim was to go to Cape Adare, the north-easternmost peninsula of Victoria Land, and overwinter there after Carsten Borchgrevink had announced in London at the International Geographical Congress in 1896 that this site was suitable for overwintering on land (Borchgrevink 1896). The expeditioners loaded on the ship a prefabricated hut to serve as shelter for the four members of the expedition who were to overwinter at Cape Adare. During the overwintering, the Belgica ship was to go to Melbourne with the rest of the expeditioners, then carry out some exploration in the Pacific Ocean before returning to Cape Adare to retrieve the overwintering party. This, however, never happened. The ship was eventually trapped in the pack ice for some 13 months, after which time the expedition returned to Belgium.

Funds raised for the expedition amounted to approximately 12 million euros in today's financial terms and the vessel plus refurbishment cost approximately 4.2 million euros. After the expedition, the remaining funds were spent to remunerate crew members (the other staff members were not paid), plus to pay for the Belgica Prize offered on an irregular basis by the Royal Academies for Science and the Arts of Belgium. A few other small donations were also made.

It is of interest that, at the time of the departure of the expedition, the existence of an Antarctic continent was

CONTACT Patrick De Deckker patrick.dedeckker@anu.edu.au Research School of Earth Sciences, The Australian National University, Canberra ACT 2601, Australia 
Table 1. Members of the Belgica expedition. Names in boldface represent those who carried out scientific investigations.

\begin{tabular}{llll}
\hline Position & \multicolumn{1}{c}{ Name } & Nationality & Age \\
\hline Officers & Adrien de Gerlache & Remarks & 32 \\
& Georges Lecointe & Belgian & 29 \\
& Henryk Arctowski & Belgian & 26 \\
& Frederick Cook & Polish & 32 \\
& Emile Danco & American & 29 \\
& Antoni Dobrowolski & Belgian & 25 \\
& Emil Racoviță & Polish & 29 \\
& Roald Amundsen & Romanian & 26 \\
Jules Melaerts & Norwegian & 21 \\
Henri Somers & Belgian & 34 \\
Max Van Rysselberghe & Belgian & 18 \\
& Adam Tollefsen & Belgian & 31 \\
& Louis Michotte & Norwegian & 26 \\
& Ludvig H. Johansen & Belgian & 25 \\
& Engelbert Knudsen & Norwegian & 21 \\
& Gustave Dufour & Norwegian & 21 \\
& Johan Koren & Belgian & 17 \\
& Karl-Auguste Wiencke & Norwegian & 19 \\
\end{tabular}

unknown and most people in the late 1890s referred to the region around the South Pole as "Antarctide."

After a long and slow journey down the Atlantic Ocean, with the traditional festivities while crossing the Equator, the ship left Punta Arenas in Chile on 14 December 1897, and the true scientific expedition commenced. In the Beagle Channel, the scientific investigations consisted of biological, geological and oceanographical observations to which anthropological interests were added, duly supported by high-quality photography. Several members of the scientific party took an interest in the local aboriginals and at least three expeditioners each collated a small dictionary of terms of interest to their fields of specialization. These are reported in personal diaries and other publications.

On 14 January 1898 the exploration of Drake Passage began and the sounding and oceanographic work truly commenced. The project aimed to determine if the Andean chain of mountains and volcanoes continued under water in shallow depths. The first discovery was that the ocean in that region is much deeper than previously thought, with the cable having to be lowered more than $4000 \mathrm{~m}$ ! The first iceberg was seen and collision with one occurred. Sadly, during a major storm, the first casualty of the expedition took place: the young Karl Auguste Wiencke fell overboard and could not be rescued despite an attempt to reach him in the cold waters by the second-in-command, Georges Lecointe.

The voyage continued and on 23 January a new passageway was discovered and explored. On the earliest published maps, it was called Belgica Strait, but was later renamed Gerlache Strait, in honour of the commander, who had conceived this exploration in Antarctic waters. Mapping proceeded efficiently using a variety of geodetic techniques, many of which relied on positioning with planets done by Lecointe, who was a master of marine navigation, having published an important book, entitled La navigation astronomique et la navigation estimée (Lecointe 1897), on marine navigation before he joined the expedition. During his mapping exercises, Lecointe was aided by de Gerlache and several other members of the expedition. Of interest is that Lecointe used the Mouchez method to identify the height of all the islands and peaks (see Derwael 2013). Those excellent maps are still the common reference today (see Supplementary Figs. S1-3). Up to 70 new names were given to discovered islands and other geographical features, many of which bear the names of benefactors, friends, relatives and Belgian localities, such as Brabant and Liège islands. These names pertain today (BELSPO no date; see Supplementary Fig. S1).

During the 20 days of investigations in Gerlache Strait, many members of the scientific crew, aided by others at times, collected biological and geological specimens on land and conducted oceanographic observations. The biologist Emil Racoviță made several discoveries, including a flightless midge fly that was later formally named Belgica antarctica by the Belgian medical doctor and entomologist Jean-Charles Jacobs. Racoviță also found the first flowering plants to be collected on the Antarctic Peninsula. The Polish Henryk Arctowski, who had been educated at the University of Liège and had been trained in glaciology by Austrian and Swiss experts before the expedition, identified evidence of an extensive and older glaciation, which he assumed (correctly) was synchronous with the major glaciation in the Northern Hemisphere. In the meantime, Racoviță made plentiful observations on the behaviour of penguins, whales and seals (see Murariu 2016), and collected numerous organisms.

Having left Gerlache Strait on 13 February, the vessel eventually became trapped in the pack ice and drifted erratically over some $2000 \mathrm{~km}$ during 13 months (see Supplementary Figs. S2, S3). During this period, signs of scurvy prevailed and many members of the expedition suffered from "polar anoemia." Health conditions are reported in many of the diaries left by members of the expedition. Fortunately, the American 
doctor Frederick A. Cook, who had spent time observing Inuits in the Arctic recommended the consumption of raw penguin and seal meat and exposure to ultraviolet light from burning flames from a stove. Sadly, the former army officer Emile Danco, who had retrained to take geomagnetic measurements during the voyage, died of heart failure. His death seriously affected the personnel at a time when they were facing total darkness during the polar winter. Nevertheless, scientific investigations continued, despite the fear of the ship being crushed by moving forces in the pack ice and large icebergs ploughing through it. Once the ship was nearly struck by a large iceberg.

The return voyage to Europe took a long time, as the expedition had run out of coal to fuel the steam engine. The Belgica's arrival in Antwerp on 5 November 1899 was a day of celebration.

\section{Publication of the results}

Upon the expedition's return, most of the Belgica biological, geological and other collections were dispatched by the members of the Royal Belgian Museum of Natural Sciences (its name at that time) in Brussels to experts in Belgium and many parts of Europe. The Belgica Commission (Commission de la Belgica) funded the expedition-related publications and also the preparation of many of the scientific illustrations, some of which are superb examples of scientific artistic work. Many of these illustrations are in colour.

Collating and publishing the results lasted for more than 40 years. Two members of the scientific expedition, Georges Lecointe and Emil Racoviță, spent much time over the years coordinating and facilitating the publication of the Résultats by liasing between the authors and the publisher. It was not an easy task, as correspondence kept in numerous archives held in Europe reveal. Antoni Dobrowoslki replaced Georges Lecointe for the final publication on account of the latter's illness and premature death.

The publications were mostly biological, geological, geophysical, meteorological, oceanographic and anthropological, with reports appearing years later in numerous scientific journals and magazines, but principally in a series of monographs published under the auspices of the Belgica Commission that was funded by a generous grant from the Belgian government at the recommendation of the King Leopold II. It was entitled Résultats du voyage de la Belgica en 1897-99 sous le commandement de A. de Gerlache de Gomery - rapports scientifiques. In total, nine volumes (totalling 92 contributions in 65 issues) appeared sporadically over many years, the last one in 1949; 64 of those contributions were dedicated to biological investigations and the rest principally to astronomy, climatology, glaciology, mapping, navigation, as well as geology, geophysics, meteorology and oceanography. Originally, 109 contributions had been planned, but several never appeared for a variety of reasons. Copies of the published volumes were sent to 500 addresses around the world (see Anonymous 1904). Many of the recipients of the volumes were dignitaries rather than research institutions and university libraries, which may explain why they are today rarely found and are often poorly catalogued. Of the scientific results, 980 pages dealt with non-biological observations and 1892 pages were of biological interest. In comparison, the results of the British Southern Cross expedition, which was the first to overwinter on the Antarctic continent, in 1899, were published in a single volume edited by Lankester (1902), then Director of the British Museum, and consisted of only 344 pages (although in small type with tight spacing). No anthropological results appeared in the Résultats series, despite being long anticipated.

A complete list of the publications related to the Belgica expedition appeared in a compendium of those publications presented by De Broyer \& Kuyken (2001) in the book celebrating the Belgica expedition centennial and co-authored by Decleir \& De Broyer (2001). In total, over 800 articles, books and other publications related to the Belgica expedition were listed by De Broyer \& Kuyken (2001), with more still appearing in the scientific literature.

A complete array of the Résultats series are held in the library of the Royal Belgian Institute of Natural Sciences in Brussels and most volumes are also available digitally at the website of the Flanders Marine Institute in Ostend (http://www.vliz.be). Several other libraries in the world also hold several of these volumes.

In addition to these scientific publications, all the senior members of the expedition wrote diaries, and there is also a number of unpublished diaries by other members of the crew. In chronological order of publication, these are: Dobrowolski (1899); Cook (1900); de Gerlache (1902); Arctowski (1903); Lecointe (1904); Dobrowolski (1950); Dobrowolski (1962); Decleir's edited translation of Amundsen's diary (1999); the reproduction by Marinescu (1996) and Marinescu et al. (1998) of Racoviță's diary; Amundsen (2009). Several of these diaries have been translated into different languages and some also reprinted. Disappointingly, many errors have been inserted, and whereas some have had material added, others have suffered from omissions. Readers are urged to refer to the originals. The unpublished diaries of members of the crew are those of Johan Koren, Karl-Auguste Wiencke and Jan van Mirlo. The Fram Museum in Oslo will eventually publish these and have them translated into English (G. Kløver, pers. comm.).

Several lengthy publications appeared in the scientific literature after the expedition. These were by Arctowski (1900, 1901a,b), de Gerlache (1900), 
Lecointe (1900a,b,c), Racoviță (1900a,b) and de Gerlache (posthumously in 1938).

\section{Dissemination of the scientific results}

Many of the results of the scientific investigations pertaining to the Belgica expedition have been ignored for more than a century. There are several possible reasons why the results have been ignored, one being that for a long time scientists were simply unaware of the existence of all the monographs published by the Belgica Commission. The other is that most of the scientific publications are in French and some are in German.

Among the important works that have omitted Belgica results is the well-consulted and frequently updated international oceanographic reference The World Ocean Atlas. (Levitus \& Boyer 1994). This atlas does not mention the oceanographic findings of the first Belgica expedition presented by Arctowski \& Mill (1908), and yet oceanographic data from subsequent Belgica expeditions in the Arctic and Atlantic oceans are listed.

Also surprising is the absence of Belgica research and achievements in many of the folios published in the Antarctic Map Folio Series by the American Geographical Society of New York and edited by Bushnell (1964-1975). For example, in Folio 3, edited by Whitmore (1965), there is mention of a map of Gerlache Strait that is at a scale of 1:462 000 prepared by "Belgium" but no reference is made to the maps or publication of Lecointe (1903). The geological map of the Antarctic Peninsula published in Folio 12 in the series (Adie 1969) contains no reference to the relevant findings made during the Belgica expedition - neither on the map nor in the lengthy list of references. Detailed geological reports were published on the petrology and geochemical analyses of the rocks collected by Henryk Arctowski on many of the islands of Gerlache Strait (Arctowski 1900, 1901b; Pelikan 1909). (Disappointingly, no geological map was ever published as a result of these investigations as Professor Alphonse Renard of the University of Gent, in Belgium, who was supposed to write a report on the geological investigations of the Belgica expedition, died in 1903 before he could accomplish this task.) Folio 19 (Dater 1975) deals with the history of Antarctic exploration and scientific investigation but briefly mentions just two publications by Arctowski (1901a,b) and a two-page article in Nature (J.W.G. 1906). The Résultats is listed but no details are provided. Nevertheless, a brief description of the Belgica expedition is provided on Sheet 3 and is accompanied by a small map on Plate 4 that shows the ship's track in Gerlache Strait. In Folio 13 (Gordon \& Goldberg 1970), which is oceanographic, the map (Plate 1) showing transect points in the Drake Passage area prior to 1931 does not seem to show any sign of the Belgica soundings listed and described by Arctowski \& Mill (1908). In Folio 5 (Greene et al. 1967), which presents a survey of terrestrial life in Antarctica, there is no mention in the references of any of the publications in the Résultats series. The sketch of the flightless chironomid fly Belgica antarctica that appears in one of the maps in Folio 5 is not the original drawing by Jacobs, which is of better quality than the one shown.

More recent examples include an article about climate variability through time in the Bellingshausen Sea (Jacobs \& Comiso 1997). It briefly mentions Frederick Cook's journal (Cook 1900) but does not discuss any of the climatological and oceanographical data obtained by the Belgica expedition. Other examples are highresolution mapping work of the sea floor in Gerlache Strait (Canals et al. 2000; Amblas et al. 2006; Ó Cofaigh et al. 2014; Lavoie et al. 2015), which have identified glacial features, such as drumlins and mega-scale glacial lineations. None of these papers refer to the pioneering work of Arctowski, the Belgica geologist, on the islands bordering Gerlache Strait (Arctowski 1901a, 1908), where he identified ancient moraine deposits, which he concluded belonged to a much more important period of glaciation. Arctowski had pointed out that the past movement of the glaciers would have been towards the strait, as Ó Cofaigh et al. (2014) later confirmed, without citing Arctowski.

\section{The Belgica scientific data and global change}

The Antarctic ice-sheet surface has been warming, with the Antarctic Peninsula undergoing the largest temperature increases (Steig et al. 2009). Arctowski (1904) gathered meteorological data from the Belgica expedition in an extensive monograph. There is ample information on atmospheric pressure, air temperature and humidity, some of which is presented through reproduction of instrumental charts in a set of 23 plates. The timing of meteorological data gathering, from 1 March 1898 to 12 March 1899, coincides with the period when the ship was trapped in the pack ice and drifted in sometimes an erratic way (see Supplementary Fig. S3). Some of these data need to be digitized and will become very useful when assessing meteorological conditions 120 years ago for comparison with data acquired over the last few decades. There is also a good set of meteorological information (air temperature, humidity, cloudy days, rainfall and type of weather, wind) gathered by Louis Bernacchi at Cape Adare in Victoria Land and summarized in his book (Bernachi 1901) worthy of comparison with the Belgica expedition data as the instruments were recording during approximately the same period of time. Some of the original data plots may be held by the British Antarctic Survey. Arctowski (1904) provided information on wind speed as well that can be considered in line with the other ample meteorological observations made by Dobrowolski (1903) on clouds. It should also be noted that meteorological information was gathered in 1903-05 during the Le 
Français expedition (Charcot 1906) and in 1908-1910 during the Pourquoi Pas? expedition (Charcot 1910).

Recent ice loss in the Antarctic, in particular along the Antarctic Peninsula is forcing major oceanographic changes (McMillan et al. 2014). Sea-surface temperatures are increasing and salinity is decreasing. Spence et al. (2017) have identified that localized changes in coastal winds off East Antarctica can produce significant subsurface temperature anomalies $\left(>2^{\circ} \mathrm{C}\right)$ around much of the continent. These authors illustrated a shoaling of isopycnals that brings warm, deep water upwards and towards the coast driving subsurface warming. This, in turn, affects sea-ice behaviour and the entire food web (see, for example, Deppeler \& Davidson 2017). The oceanographic data collated by Arctowski \& Mill (1908) would help us better understand some of the changes that have occurred over 120 years in Drake Passage, and examination of Emil Racoviță's diaries, held at the Grigore Antipa Museum in Bucharest, might provide a useful backdrop for modern studies of marine biological and ecological change in the region. For example, Cimino et al. (2013) have identified that Pygoscelis penguin species are experiencing broad population changes that are parallel with decadal-scale trends in remote-sensed observations of sea-ice concentrations and sea-surface temperatures during the chick-rearing season, especially along the West Antarctic Peninsula. According to Cimino et al. (2016), ongoing climate change will seriously impact these penguins and a southward contraction in their range is likely over the next century. Ashton et al. (2017) have documented that seabed life assemblages registered a nearly doubled growth under a $1^{\circ} \mathrm{C}$ rise in sea temperature, whereas a $2^{\circ} \mathrm{C}$ rise produced divergent responses.

\section{Conclusion}

The Belgica expedition proved to be an extremely productive partnership by just a few outstanding young scientists who made sure their data be published. The amount of published information is somewhat staggering and yet it has not been adequately utilized by scientists over the last few decades. Reasons for this ignorance may be explained by the fact that many of the publications were in French and not easily accessible. The situation has now changed with digitized versions of most publications readily available and it is hoped that this article will inform in particular people who are aiming at assessing environmental change in the vicinity of the Antarctic Peninsula by returning to data gathered 120 years ago.

\section{Acknowledgements}

I am particularly grateful to many of the librarians who helped find publications related to the Belgica expedition. These are Kirsty Summers at Sydney University, Anne Melgåd and Guro Tangvald of the National Library of Norway, Nathalie Wagemans of the Museum aan de Stroom in Antwerp, as well as Marie Depris of the Royal Belgian Institute of Natural Sciences in Brussels, Agnieszka Pietrzak of the Muzeum Ziemi in Warsaw and Bogdan Cracium of the National Archives Library in Cluj and finally many staff members of the Australian National Library in Canberra. In addition, I am grateful to Emeritus Professor Dimitru Murariu of the Grigore Antipa Museum in Bucharest for guiding me through many of the E. Racoviță archives and to Professor Claude De Broyer of the Royal Belgian Institute of Natural Sciences in Brussels for facilitating my examination of all the Belgica volumes and other archives. Discussions concerning many of the Belgica archives with Olivier De Schrevel proved extremely fruitful. I am also grateful to both Emeritus Professors Claude De Broyer and Dimitru Murariu for their detailed reviews of this paper. Thank you all.

\section{Disclosure statement}

No potential conflict of interest was reported by the author.

\section{ORCID}

Patrick De Deckker (D) http://orcid.org/0000-0003-30035143

\section{References}

Adie J.R. 1969. Sheet 1. Northern Antarctic Peninsula. In C. Craddock et al. (eds.): Geologic maps of Antarctica. Antarctic Map Folio Series. Folio 12. New York: American Geographical Society.

Amblas D., Urgeles R., Canals M., Calafat A.M., Rebesco M., Camerlenghi A., Estrada F., De Batist M. \& HughesClarke J.E. 2006. Relationship between continental rise development and palaeo-ice sheet dynamics, Northern Antarctic Peninsula Pacific margin. Quaternary Science Reviews 25, 933-944.

Amundsen R. 2009. Belgicaekspedisjonen 1897-1899: den første overvintring $i$ Antarktis. (The Belgica expedition, 1987-1899: the first overwintering in Antarctica.). G. Kløver (ed.) Oslo: Fram Museum.

Anonymous 1904. The Belgian Antarctic Expedition under the command of A. de Gerlache de Gomery. Summary report of the voyage of the "Belgica" in 1897-1898-1899. Brussels: Royal Academy of Belgium.

Arctowski H. 1900. Géographie physique de la région Antarctique visitée par l'expédition de la Belgica. (Physical geography of the Antarctic region visited by the Belgica expedition.) Bulletin de la Société Royale Belge de Géographie 24, 93-175.

Arctowski H. 1901a. Exploration of Antarctic lands. The Geographical Journal 17, 150-180.

Arctowski H. 1901b. The Antarctic voyage of the Belgica during the years 1897-1898, 1899. The Geographical Journal 18, 353-394.

Arctowski H. 1903. Die antarktischen Eisverhältnisse. Auszug aus meinen Tagebuch der Südpolarreise der Belgica 1898-1899. (Antarctic ice conditions. Excerpt from my diary of the South Polar journey of the Belgica, 
1898-1899.) Petermanns Geographische Mitteilungen (Gotha), Ergänzungsheft 144. Gotha: J. Perthes.

Arctowski H. 1904. Rapport sur les observations météorologiques horaires. (Report on the hourly meteorological observations.) Résultats du voyage de la Belgica en 1897-1898-1899 - rapports scientifiques. Météorologie. (Results of the Belgica voyage in 1897-1898-1899 - scientific reports. Meteorology.) Antwerp: Imprimerie J. Buschmann.

Arctowski H. 1908. Les glaciers. Glaciers actuels et vestiges de leur ancienne extension. (Glaciers. Modern glaciers and relicts of their past extent.) Résultats du voyage de la Belgica en 1897-1898-1899 - rapports scientifiques. Géologie. (Results of the Belgica voyage in 1897-1898-1899. Scientific reports. Geology.) Antwerp: Imprimerie J. Buschmann.

Arctowski H. \& Mill H.R. 1908. Rapport sur les relations thermiques de l'océan. Rapport sur les observations thermométriques faites aux stations de sondage. (Report on the thermic relationships of the ocean. Report on the thermometric observations carried out at the sounding stations.) Résultats du voyage de la Belgica en 1897-18981899 - rapports scientifiques. Océanographie. (Results of the Belgica voyage in 1897-1898-1899 - scientific reports. Oceanography.) Antwerp: Imprimerie J. Buschmann.

Ashton G.V., Morley S.A., Barnes D.K.A., Clark M.S. \& Peck L.S. 2017. Warming by $1^{\circ} \mathrm{C}$ drives species and assemblage level responses in Antarctica's marine shallows. Current Biology 27, 2698-2705.

BELSPO no date. Four maps representing Belgian toponyms in Antarctica. Brussels: Belgian Science Policy Office. Available on the internet at http://www.belspo.be/bel spo/BePoles/publ/poster\%20antarctique_3.pdf.

Bernachi L.C. 1901. To the South Polar regions: expedition of 1898-1900. London: Hurst and Blackett.

Borchgrevink C.E. 1896. The voyage of the "Antarctic" to Victoria Land. In The Secretaries. (eds.): Report of the Sixth International Geographical Congress held in London 1895. Pp. 169-176. London: John Murray.

Bushnell V.C. (ed.) 1964-1975. Antarctic Map Folio Series. New York: American Geographical Society.

Canals M., Urgeles R. \& Calafat A.M. 2000. Deep sea-floor evidence of past ice streams off the Antarctic Peninsula. Geology 28, 31-34.

Charcot J.-B. 1906. Autour du Pôle Sud. Expédition du "Français": journal de l'expédition antarctique française, 1903-1905. (Around the South Pole. Expedition of the Français: diary of the French Antarctic expedition, 1903-1905.) Paris: E. Flammarion.

Charcot J.-B. 1910. Autour du Pôle Sud. Expédition du "Pourquoi-Pas?" dans l'Antarctique: journal de la deuxième expédition au Pôle sud, 1908-1910, suivi des rapports scientifiques des membres de l'état-major. (Around the South Pole. Expedition of the Pourquoi Pas? In Antarctica: diary of the second expedition to the South Pole, 1908-1910, followed by the scientific reports of the scientific staff.) Paris: E. Flammarion.

Cimino M.A., Fraser W.R., Irwin A.J. \& Oliver M.J. 2013. Satellite data identify decadal trends in the quality of Pygoscelis penguin chick-rearing habitat. Global Change Biology 19, 136-148.

Cimino M.A., Lynch H.J., Saba V.S. \& Oliver M.J. 2016. Projected asymmetric response of Adélie penguins to Antarctic climate change. Scientific Report 6, article no. 28785, doi: 10.1038/srep28785.

Cook F.A. 1900. Through the first Antarctic night. A narrative of the voyage of the Belgica among newly discovered lands and over an unknown sea about the South Pole. New York: Doubleday \& McClure Co.
Dater H.M. 1975. History of Antarctic exploration and scientific investigations. Antarctic Map Folio Series. Folio 19. New York: American Geographical Society.

De Broyer C. \& Kuyken T. 2001. Bibliography of the Belgica Antarctic expedition 1897-1899. In H. Decleir \& C. De Broyer (eds.): The Belgica expedition centennial. Pp. 327-360. Brussels: VUB Press.

de Gerlache A. 1900. Relation sommaire du voyage de la "Belgica." (Brief summary of the voyage of the Belgica.) Bulletin de la Société Royale Belge de Géographie 24, 365415.

de Gerlache A. 1902. Voyage de la Belgica. Quinze mois dans l'Antarctique. (Voyage of the Belgica. Fifteen months in Antarctica.) Bruxelles: Imprimerie Scientifique Ch. Bulens.

de Gerlache A. 1938. Fragments du récit de voyage. (Fragments of the travelogue.) Résultats du voyage de la Belgica en 1897-1899 - rapports scientifiques. (Results of the Belgica voyage in 1897-1898-1899 - scientific reports.) Antwerp: Imprimerie J. Buschmann.

Decleir H. (ed.) 1999. Roald Amundsen's Belgica diary. The first scientific expedition to the Antarctic. Norwich: Erskine Press.

Decleir H. \& De Broyer C. 2001. The Belgica expedition centennial. Brussels: VUB Press.

Deppeler S.L. \& Davidson A.T. 2017. Southern Ocean phytoplankton in a changing climate. Frontiers in Marine Science 4, doi: 10.3389/fmars.2017.00040.

Derwael J.-J. 2013. Méthode de l'Amiral Mouchez (18211892). (Method of Admiral Mouchez [1821-1892].) Revue XYZ 134, 61-66.

Dobrowolski A. 1899. Belgijska wyprawa antarktyczna (opowiadanie). (Belgian Antarctic expedition [story].) Atheneum 95, 240-272.

Dobrowolski A. 1903. Observations des nuages. (Cloud observations.) Résultats du voyage de la Belgica en 1897-18981899 - rapports scientifiques. Météorologie. (Results of the Belgica voyage in 1897-1898-1899 - scientific reports. Meteorology.) Antwerp: Imprimerie J. Buschmann.

Dobrowolski A. 1950. Wspomnienienia $z$ wyprawy polarnei. (Memoirs from the polar expedition.) Warsawa: Wydawnictwo Prasa Wojskowa.

Dobrowolski A. 1962. Dziennik wyprawy na Antarktyde (1897-1899). (Journal of the Antarctic expedition [18971899].) Wroclaw: Zakład Narodowy Imienia Ossolińskich.

Gordon A.L. \& Goldberg T.D. 1970. Circumpolar characteristics of Antarctic waters. Antarctic Map Folio Series. Folio 13. New York: American Geographical Society.

Greene S.W., Gressitt J.L., Koob D., Llano G.A., Rudolph E. D., Singer R., Steere W.C. \& Ugolini F.C. 1967. Terrestrial life in Antarctica. Antarctic Map Folio Series. Folio 5. New York: American Geographical Society.

J.W.G. 1906. Some results of the "Belgica" expedition. Nature 74, 289-299.

Jacobs S.S. \& Comiso J.C. 1997. Climate variability in the Amundsen and Bellingshausen seas. Journal of Climate 10, 697-709.

Lankester E.R. 1902. Report on collections of the natural history made in the Antarctic regions during the voyage of the "Southern Cross." London: British Museum.

Lavoie C., Domack E.W., Pettit E.C., Scambos T.A., Larter R.D., Schenke H.-W., Yoo K.C., Gutt J., Wellner J., Canals M., Anderson J.B. \& Amblas D. 2015. Configuration of the northern Antarctic Peninsula ice sheet at LGM based on a new synthesis of seabed imagery. Cryosphere 9, 613-629.

Lecointe G. 1897. La navigation astronomique et la navigation estimée. (Astronomical navigation and dead- 
reckoning navigation.) Paris: Librairie Militaire BergerLevrault.

Lecointe G. 1900a. Expéditon antarctique Belge. Conférence donnée à la Société Royale de Géographie d'Anvers, par Georges Lecointe, commandant en second de l'expédition. (Belgian Antarctic expedition. Conference given at the Royal Belgian Geographical Society in Antwerp by Georges Lecointe, second-in-command of the expedition.) Bulletin de la Société Royale de Géographie d'Anvers 24, 25-51.

Lecointe G. 1900b. L'Hydrographie dans le détroit de la Belgica et les observations astronomiques et magnétiques dans la zone australe. (Hydrography in the Belgica Strait and astronomical and magnetic observations in the austral zone.) Bulletin de la Société Royale Belge de Géographie 24, 53-92.

Lecointe G. 1900c. Aperçu des travaux scientifiques de l'expédition antarctique belge. (Brief description of the scientific works of the Belgian Antarctic expedition.) Bulletin de la Société Royale Belge de Géographie 24, 29-52.

Lecointe G. 1903. Travaux hydrographiques et instructions nautiques. Cartes. (Hydrographic works and nautical instructions.) Maps Résultats du voyage de la Belgica en 1897-18981899 - rapports scientifiques. Hydrographie. (Results of the Belgica voyage in 1897-1898-1899 - scientific reports. Hydrography.) Antwerp: Imprimerie J. Buschmann.

Lecointe G. 1904. Au pays des manchots. Récit du voyage de la Belgica. (The land of penguins. Diary of the Belgica voyage.) Bruxelles: Société Belge de Librairie O. Schepens \& Cie.

Levitus S. \& Boyer T. 1994. World Ocean Atlas 1994. Volume 4: temperature. NOAA Atlas NESDIS 4. Washington, DC: National Oceanic and Atmospheric Administration, US Department of Commerce.

Marinescu A. 1996. Le journal antarctique d'Emile Racovitza, naturaliste de l'expédition "Belgica." (The Antarctic journal of Emile Racovitza, natural scientist on the Belgica expedition.) Travaux $d u$ Musée d'Histoire Naturelle "Grigore Antipa" 36, 473-495.

Marinescu A., Banarescu A. \& Iftimu A. (eds.) 1998. Belgica (1897-1899). Emile Racovitza, le naturaliste de l'expédition antarctique "Belgica." Lettres, journal antarctique, conférences. (Belgica [1897-1899]. Emile Racovitza, the natural scientist of the Antarctic Belgica expedition. Letters, Antarctic diary, conferences.) Le Rameau d'Or 2. Bucarest: Fondation Culturelle Roumaine.

McMillan M., Shepherd A., Sundal A., Briggs K., Muir A., Ridout A., Hogg A. \& Wingham D. 2014 (corrected
2015). Increased ice losses from Antarctica detected by CryoSat-2. Geophysical Research Letters 41, 3899-3905.

Murariu D. (ed.) 2016. Les pinnipèdes antarctiques. Recherches d'Emile Racovitza. (Antarctic seals. Researches of Emile Racovitza.) Saarbrucken: Editions Universitaires Européenes.

Ó Cofaigh C., Davies B.J., Livingstone S.J., Smith J.A., Johnson J.S., Hocking E.P., Hogson D.A., Anderson J. B., Bentley M.J., Canals M., Domack E., Dowdeswell J. A., EvansJ., Glassner N.F., Hillenbrand C.-D., Larter R.D., Roberts S.J. \& Simms A.R. 2014. Reconstruction of ice-sheet changes in the Antarctic Peninsula since the Last Glacial Maximum. Quaternary Science Reviews 100, 87-100.

Pelikan A. 1909. Petrographische Untersuchungen der Gesteinsproben, I Teil. (Petrographic investigations of the rock samples, Part 1.) Résultats du voyage de la Belgica en 1897-1898-1899 - rapports scientifiques. Géologie. (Results of the Belgica voyage in 1897-1898-1899 - scientific reports. Geology.) Antwerp: Imprimerie J. Buschmann.

Racovitza E. 1900a. Expédition antarctique belge. La vie des animaux et des plantes dans l'Antarctique. Conférence faite à la Société Belge de Géographie. (Belgian Antarctic expedition. The life of animals and plants in Antarctica. Conference presented to the Belgian Society of Geography.) Bulletin de la Société Royale Belge de Géographie 24, 177-230.

Racovitza E. 1900b. Vers le Pôle Sud. Conférence faite à la Sorbonne sur l'expédition antarctique belge, son but, ses aventures et ses résultats. (Towards the South Pole. Conference presented at the Sorbonne on the Belgian Antarctic expedition, its goal, its adventures and its results.) Causeries Scientifiques de la Société Zoologique de France 6, 175-242.

Spence P., Holmes R.M., Hogg A.M., Griffies S.M. \& England M.H. 2017. Localized rapid warming of West Antarctic subsurface waters by remote winds. Nature Climate Change 7, 595-603.

Steig E.J., Schneider D.P., Rutherford S.D., Mann M.E., Comiso J.C. \& Shindell D.T. 2009. Warming of the Antarctic ice-sheet surface since the 1957 International Geophysical Year. Nature 457, 459-462.

Whitmore G.G. 1965. Antarctic maps and surveys 1900-1964. Antarctic Map Folio Series. Folio 3. New York: American Geographical Society. 